\title{
Revocation of Citizenship of Terrorists: A Matter of Political Expediency
}

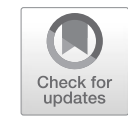

\author{
Kay Hailbronner
}

Let's be clear: We are not in a dispute about the use of denationalisation policies to get rid of unwanted citizens who do not comply with a code of conduct how to behave as a 'good' or 'loyal' citizen. Nor are we talking about deprivation or revocation of citizenship on account of race, political opinion, religion, descent etc. There are clear rules of public international law prohibiting discriminatory citizenship policies and none of the policies discussed here call these into question. What we are discussing is the different and by no means absolutely novel issue of revoking the citizenship of persons who have given up or are irrefutably considered as having renounced that basic attachment which distinguishes citizenship from a residence permit. A recent report of de Groot and Vink for the European Commission ${ }^{1}$ lists voluntary military service and non-military public service in nine, and eight EU countries respectively as a ground for revocation of citizenship, subject of course to some restrictions (prevention of statelessness) and exceptions.

In around half of the 28 countries included in the study, seriously prejudicial behaviour is considered as a ground for revocation of citizenship. The European Convention on Nationality of 6 November 1997 provides for revocation of citizenship for conduct seriously prejudicial to the vital interests of the State party (Art.7 para 1 lit.d). Very similar provisions on revocation are laid down in Art. 8 para 3 of the Convention on the Reduction of Statelessness of 1961.

What is new is the inclusion of a specific type of seriously prejudicial behaviour which is considered as endangering the safety of the population of a state and its security into this catalogue. The actors are not totalitarian or authoritarian regimes but democratic states with well-established

\footnotetext{
1 de Groot, G.-R. \& M. P. Vink (2015), A Comparative Analysis of Regulations on Involuntary Loss of Nationality in the European Union. Brussels: CEPS, available at https://www.ceps.eu/publications/

comparative-analysis-regulations-involuntary-loss-nationality-european-union
} 
institutions to protect human rights and to ensure the rule of law. Not that the democratic character of the states in question would dispense us from closely watching the transfer and exercise of powers to the executive branch, particularly in such a rights-sensitive area as denationalisation policies. Safeguards against arbitrary actions and abuse of power, conditions and procedures must be predominant on the watch list, as Peter Schuck rightly emphasizes. But why should revocation of citizenship of terrorists result inevitably in arbitrary and abusive exercise of power, as Audrey Macklin assumes?

What makes international terrorism so distinctive is not only its criminal and administrative relevance, but also its relevance for discontinuance of that special relationship established by citizenship. In order to answer this question it is not sufficient to conjure up emphatically the uniqueness of the ties between a citizen and a state. It is true that citizenship establishes a special relationship based upon security and stability. Security and stability on the side of the individual citizen require that denationalisation remains a rare exception. Citizenship implies rights, whether it is designated as a privilege, as a right to have rights or as a contract. For that reason deprivation of citizenship requires an overriding public interest and is subject to proportionality.

Ordinary crimes, even of a serious nature, have not been considered as sufficient under Art. 7 of the European Convention to destroy the bond of citizenship. Yet, fundamental and persistent alienation from the nation as a political community has - in spite of divergent interpretations and applications - frequently been considered as a justification for revocation of citizenship. Democratic states in the defence of their constitutional order and protection of the safety of their population and the security of the state are not restricted to a regime of criminal and administrative sanctions if their own nationals turn against them.

Legal comparison shows that there is no uniformity. States, according to their particular political conditions, and history that is sometimes reflected in constitutional provisions, have largely prohibited involuntary revocation of citizenship. Germany is one example, though it provides for loss of citizenship for voluntary service in foreign military services or in case of voluntary acquisition of a foreign citizenship. Other states, like Britain, have applied the concept to high treason, espionage, etc. International treaties, like the European Convention on Nationality of 1997 or the Convention on the Reduction of Statelessness provide further barriers. States may not provide for the loss of nationality if the person concerned would become stateless (except in case of fraud). One could discuss what this means if a state's 
national joins a group or organisation, such as the 'Islamic State', which is dominating a state-like territory and exercises state-like authority.

Discussion of the international and constitutional law prerequisites of revocation of citizenship is not the concern of Audrey Macklin. She argues primarily with illegitimacy. As a lawyer I have some difficulty with this term. If it is not illegal, what are the criteria for illegitimacy or immorality? Her personal idea of how democratic states should behave? That of course may be an acceptable political reasoning, provided I learn more about its ideological premises which I may share or not. I do understand Peter Spiro's objection about the revocation of citizenship as a 'security theatre' although I feel not confident on the basis of the facts to judge whether it is true that revocation of citizenship for international terrorists is impractical and irrelevant. The arguments of illegitimacy, in my view are hardly convincing. Assuming that revocation of citizenship is a (prohibited) form of punishment simply ignores the legal nature of revocation of citizenship. It is not destined to sanction acts of international terrorism, in addition to a potential criminal or administrative sanction. By untying the bond of citizenship, the former citizen can no longer rely upon his/her citizenship for unlimited entry and residence and free international travel. The further argument that there is no chance of rehabilitation is based on the same misunderstanding of revocation of citizenship as a special form of punishment. Citizenship of such persons is revoked because they have given up their attachment to a community by attacking the very fundament of that community, not by merely violating its internal rules of public order. To talk in this context of an inalienable right of rehabilitation, distorts the purpose of citizenship revocation.

The hard questions arise with the formulation of a precise and judicially reviewable provision authorising the executive to revoke citizenship. International terrorism as such is a term open to divergent interpretations. We do, however, have quite some experience, based upon the jurisprudence of national and international courts and Security Council Resolutions, in defining international terrorism. In order to be effective, a provision must include such actions as joining extremist organisations for training in order to use such training for participation in terrorist activities, as well as a membership in an organisation destined to fight against the state whose citizenship the person concerned possesses.

A further question is whether the introduction of a new provision on revocation of citizenship serves a useful purpose. Utility cannot be denied by reference to criminal law. It goes without saying that acts of international terrorism should be punished and that administrative action should, where 
possible, be taken to limit the use of passports for international travel for the purpose of preparing or assisting international terrorism - the technical and cynical use of citizenship rights, as Peter Schuck has phrased it. Criminal and administrative sanctions are always attached to specific activities. They do not cover the aspect of using citizenship in a general and in principle unforeseeable manner for acts destined to endanger the security of the state of which the perpetrators are citizens.

The cosmopolitan nature of this type of terrorism, as Christian Joppke has aptly described it, is misunderstood by Vesco Paskalev when he argues that the jihadists do not care about their citizenship. They might indeed not care about their attachment to the state whose citizenship they posses but they do care about the possibilities that a Canadian, US, British or German passport conveys with visa-free international travel, free entry and residence in their 'home' country and diplomatic protection if something does not go quite as smoothly as expected.

Revocation of citizenship means a substantial interference with individual rights. It can only be justified if tightly defined material conditions in accordance with the constitutional law of each country and its international commitments are fulfilled. Risk assessment and proof of an affiliation, assistance or membership in an international terrorist organisation will be essential elements in this procedure. Whether there is a practical value in revocation of citizenship for citizens engaged in international terrorism in addition to criminal and administrative sanctions is within the framework of law a matter of political expediency which may well lead to different results in different countries.

Open Access This chapter is licensed under the terms of the Creative Commons Attribution 4.0 International License (http://creativecommons.org/licenses/by/4.0/), which permits use, sharing, adaptation, distribution and reproduction in any medium or format, as long as you give appropriate credit to the original author(s) and the source, provide a link to the Creative Commons license and indicate if changes were made.

The images or other third party material in this chapter are included in the chapter's Creative Commons license, unless indicated otherwise in a credit line to the material. If material is not included in the chapter's Creative Commons license and your intended use is not permitted by statutory regulation or exceeds the permitted use, you will need to obtain permission directly from the copyright holder.

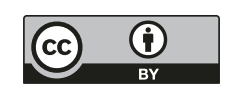

